\title{
Microscopic study of bacteria-textile material interaction for hygienic purpose
}

\author{
J. M. M. Malheiro* and L. R. S. Salvado*
}

* Textile and Paper Materials Research Unit, University of Beira Interior, Av. Marquês Ávila Bolama, 6201-001 Covilhã, Portugal

joanamouramalheiro@gmail.com

Underwear is the most intimate form of dress, and feminine panties are particularly in close contact with genital mucosa, vulvar skin and perineum area. In fact, despite some controversy, the textile material has been pointed out as promoter of vaginal infection, trough changes on the normal skin physiology $[1,2]$. The physiology of vulvar skin is very specific in terms of temperature $\left(\approx 34^{\circ} \mathrm{C}\right)$, moisture and $\mathrm{pH}(<4.7)$. This region is also colonized by a very specific microflora that is essential either to protect against pathogenic microorganisms, either to maintain healthy conditions of temperature, moisture and $\mathrm{pH}[1,2]$.

Underwear is usually washed at temperatures up to $40^{\circ} \mathrm{C}$, because of energy economy, environmental issues, delicateness of fabrics or dyes... However, it has been showed that at $60^{\circ} \mathrm{C}$ only some species of bacteria are eliminated from textile structures. Thus, common domestic laundry may not eliminate bacteria from textile structures leading to bacteria persistency on these structures and potentially causing re-infection [3].

Evidences show that bacteria present higher propensity to colonize surfaces rather to stay in suspension, and the colonization of a surface begins with a complex mechanism - bacterial adhesion. The bacterial adhesion depends on physic-chemical characteristics of the bacteria (bacteria specie, surface energy, zeta potential and presence of biofilm), material surface (chemical composition, surface roughness, morphological configuration, zeta potential and surface energy) and suspension medium (type of medium, temperature, exposing time, bacteria concentration, surface tension and flow shear stress) [4]. Thus, microscopic technologies are of great importance for the characterisation of all the subjects involved in the adhesion mechanism, contributing to better understand the interaction between the bacteria and the textile material surface.

In this work, morphological configuration - cross section and surface roughness - of diverse but common textile fibres, such as lyocell, viscose, cotton and polyesters, were analysed by SEM (Scanning Electron Microscopy) technology. These textile fibres have the ability to hydrate at standard conditions, causing surface damaging by the electron beam. To avoid this effect, the fibres were dehydrated using the Critical Point Drying technique [4].

Cotton (Fig. 1-a) has a very irregular morphology and it has microfibrils on the surface (Fig. 2-b). Bamboo Viscose (Fig. 1-b) has lengthwise streaks but it does not have microroughness. Lyocell (Fig. 1-c) is longitudinally smooth and does not have microroughness (Fig. 2-a); however its usage lead to fibrillation and consequently to coming out of surface microroughness. Polyester fibres have a wide range of shapes. In this study three different shapes were considered: circular cross section (Fig. 1-d), an irregular one with 4 longitudinal channels (Coolever ${ }^{\mathbb{B}}$ ) (Fig. 1-e) and other one with multiple, deeper and irregular channels (4-DG $\left.{ }^{\circledR}\right)$ (Fig. 1-f).

Two species of bacteria that are frequently found in the vaginal ecosystem are the Staphylococcus aureus (bacteria coccus shaped, have capsule and produce slime to attach on surfaces) and E. coli (bacteria bacilli shaped and have nano-fimbriae to attach on surfaces) [5].

Comparing the morphologies of both - the studied fibres and bacteria - one may conclude the morphological scale of the irregularities of fibres is close to bacteria size. Also, surface 
microroughness of fibre has similar scale as extracellular appendices of bacteria. Thus, considering only the morphology of fibres with the same chemical composition and knowing that theoretically the more irregular configuration of fibres the higher adhesion, adhesion of bacteria to the fibre surface might be increased by irregularity of the cross section of fibres. And taking into account the micro-roughness of fibres with the same chemical composition, it is also expected that bacterial adhesion will increase with increasing roughness by increasing surface area and giving physical protection to bacteria, promoting deposition and adhesion of bacteria and subsequent formation of biofilm.

To sum up, the choice of fibres for underwear should take into account the influence of the fibre morphology on bacteria adhesion.

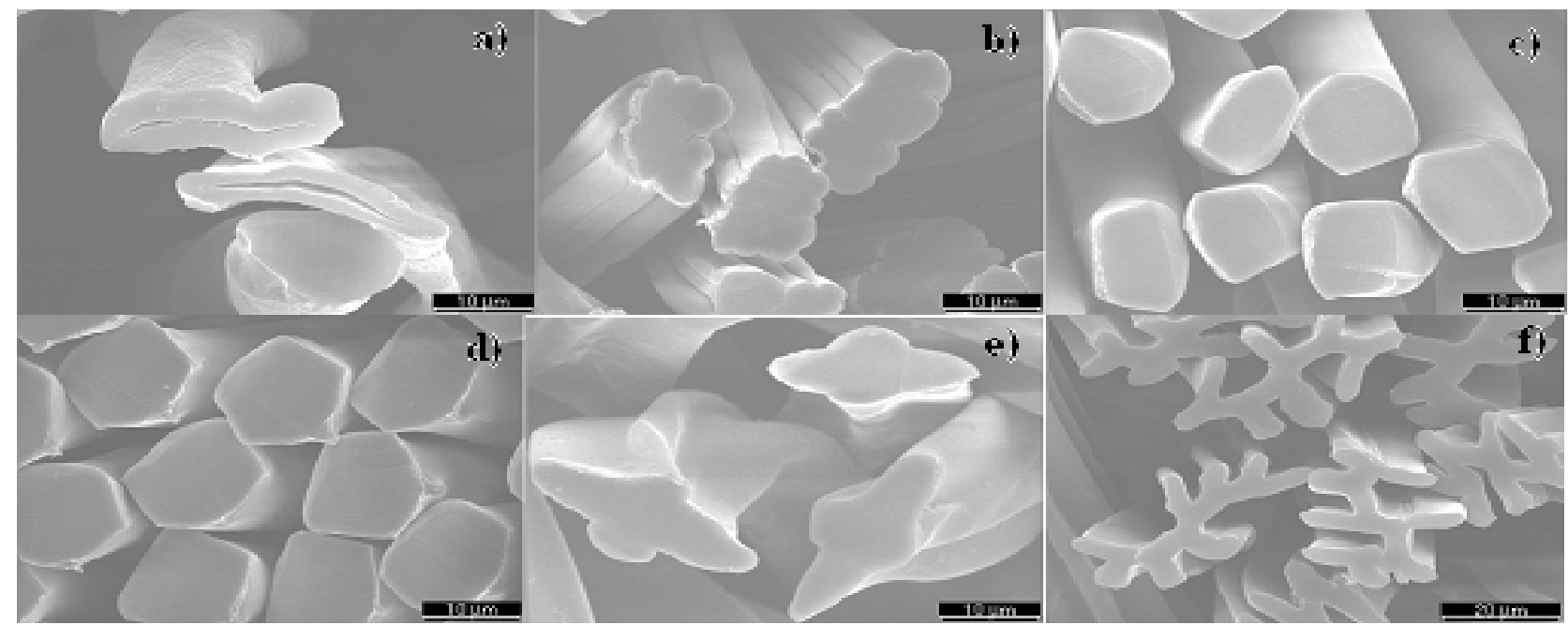

Fig. 1. Cross-section view of the different fibres: a) Cotton; b) Bamboo Viscose; c) Lyocell; and Polyester: c) round section; d) Coolever ${ }^{\circledR}$; e) 4-DG ${ }^{\circledR}$.

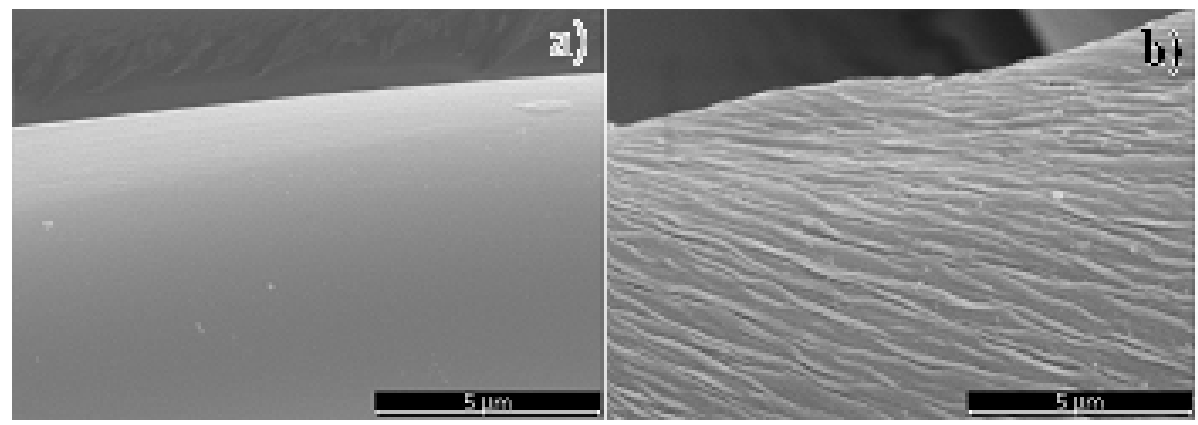

Fig. 2. Longitudinal section view (surface detail) of: a) Lyocell and b) Cotton.

References

[1] B.Runeman, G.Rybo, U.Forsgren-Brusk, O.Larkö, P.Larsson, J.Faergemann, Acta Derm Venereol, 84 (2004) 277.

[2] B.Runeman, G.Rybo, U.Forsgren-Brusk, O.Larkö, P.Larsson, J.Faergemann, Acta Derm Venereol, 85 (2005) 118.

[3] B. Ossowski, U. Duchmann, W. Boslet, Geburtshilfe und Frauenheilkunde, 59(4) (1999) 175.

[4] H Yuehuei, R. J. Friedman, eds. Handbook of Bacterial Adhesion, Human Press (2000).

[5] www.sciencephoto.com 